\title{
The Effect of Leg Muscle Strengh, Leg Muscle Explosion Power, and Reaction Speed on the Side Kunging Degree Capability
}

\author{
Nissa Aldani ${ }^{*}$, Gusril $^{2}$, and Alnedral ${ }^{3}$ \\ 1,2,3 Faculty of Sports Sciences, Universitas Negeri Padang Padang, Indonesia \\ "Corresponding author. Email: nissaaldani060893@gmail.com
}

\begin{abstract}
The study aims to reveal the direct and indirect effects of exogenous variables on endorgent variables. The research method is a quantitative Path Analysis approach. The study population was all athletes in the Tarung Derajat Padang city of 110 sports, consisting of 60 men and 50 women. Sampling with Purposive Sampling technique, so that the sample is male athletes totaling 60 people. Data collection on leg muscle strength with Leg Dynamometer, leg muscle explosive power with the Standing Broad Jump Test, reaction speed by measuring the athlete's foot reaction speed, and side kick ability by doing side kicks for 1 minute. The results showed that: (1) there was a direct influence on leg muscle strength on the ability of side kick with py1 $=0.289$, (2) there was a direct effect on leg muscle explosive power on the ability to kick side with py $2=0.345$, (3) there was a direct effect on speed reaction to the ability of the side kick with py $3=0.293$, (4) there is an indirect effect of leg muscle strength on the ability of the side kick through the reaction speed with py31 $=0.1058$, (5) there is an indirect effect of leg muscle explosive power on the ability of the side kick through the reaction speed with py32 $=0.1468$, and (6) there is an influence of leg muscle strength, leg muscle explosive power and the speed of reaction simultaneously on the ability of the side kick with py321 $=0.562$.
\end{abstract}

\section{Keywords: Leg Muscle Strength, Leg Muscle Explosion Power, Reaction Speed, Side Kick Ability}

\section{INTRODUCTION}

Tarung Derajat is one of the branches of achievement sports which is gaining popularity among the people and the world. Fighting martial arts degree is not only carried out by certain age groups, but has been thoroughly all ages, ranging from children, adolescents, adults to parents at this age. This is also marked by the rapid development of Satlat (Training Unit) which has entered all Regencies / Cities of all Provinces in Indonesia, and has been entered in all Southeast Asian countries, namely the Sea Games since 2011 in Jakarta. Sports created by native sons of Indonesia are known to be quite hard and uphold a sense of brotherhood that teaches all members to train morally and mentally as implemented by its creator, namely Teacher H. Achmad Derajat who is commonly called "Mortal Ghada".

Tarung Derajat to use the rules Combat sports to use the rules of the Central College \& Statutes and Bylaws PB Kodrat 2013[1]. Sports combat is: "science, moral actions and life attitudes that utilize the ability of muscle power, brain and conscience realistically and rational, especially in the effort of mastering and applying the 5 elements of moral mobility, namely: Strength, Speed, Accuracy, Courage and Tenacity in an aggressive and dynamic defense and defense system in the forms of movement, punch, kick, rebuttal, slamming, locking, avoidance, and other important limb movements patterned on techniques, tactics and defense and attack strategies that are practical and effective for a martial arts science "(PB KODRAT, 2013: 3) [1].

Tarung Derajat was coined on July 18, 1972 which is a work of copyright of a son of the Indonesian nation is Drs. GH. Achmad Drajat, who has the nickname AA BOXER. The history of the birth of martial arts degree is known with certainty, but the martial arts degree is still not widely known by the people and government of Indonesia. This sport was born as a martial art that stands alone independently by having its own flow and container, not affiliated with other streams and other martial organizations, both those that already exist in Indonesia and those outside of the country of Indonesia and also stressed that sports fighting degree does not adopt and is not a combination of other martial arts, and does not appear by itself but has the origin of history and the source of personal life 
that comes from the greatness and majesty of God Almighty as the only basic and very influential element in forming "Human identity and something else" in accordance with His will[2].

To create a martial arts degree, the teacher learns and combines the five elements of martial arts movements, such as: hitting, kicking, parrying, slamming and evasive, from this name his name is known as AA BOXER which has extraordinary martial abilities, sure, strong, fast, precise, brave and tenacious, so he often mentions the success of fighting the degree as a philosophical basis for gestures determined by five key abilities.

After the arrangement of the boxer technique is done as the ability of muscles (physical), and the brain to balance picran (intellectual) and conscience (mental attitude). These three elements are referred to as $\mathrm{O} 2 \mathrm{~N}$ (Muscle, Brain, and Conscience) life force. The third compound is the ability to move that aims to find identity as a fighter athlete as a "Warrior Knight and Warrior Knight" then the teacher applies the motto that is: "I am friendly does not mean afraid, I submit does not mean submission". This message is always emphasized to students who pursue martial arts degrees that are formulated in every exercise.

Finally, the teacher decides to "give in to win" so that it is determined to consume KONI Pusat and PON Tarung Derajat to wear protective (BodyProtector) by using Gamsil for teeth, Shell for the groin / genitals, and Hand box for the head of the hand. The consequence of the decision taken by the Master, is the gift of victory and waiting long enough. Right on January 6, 1997, KONI Pusat decided on the acceptance of the Tarung Derajat Sports Family Management (PB KODRAT) as a regular member of KONI Pusat, number: 06 / RA / 1997. After the Tarung Derajat was officially received by the KONI Center which was registered as the 53rd member, organizationally and in all fields reforms continued to be improved. On 12-13 April 1997. Along with this activity, training of National Trainers and Referees was also held. which aims to equalize techniques to anticipate the shortage of trainers and increase the number of National Referees throughout Indonesia, and also to improve the rules for the technique of punching and kicking in matches [1].

Fighting degree has the character of a Full Body Contact or free combat that requires physical, mental, and intelligence in managing good emotions to face opponents, both in the arena of competition and outside the arena in order to use the right kicks and punches to defend themselves. This is the most important thing the fighters must possess is the basic technique for fighting. To produce a reliable fighter, of course, must be supported by adequate basic technical skills and good emotional control. Emotional intelligence and basic techniques are capital that must be possessed by a person to be a good fighter, of course, a fighter will fall from the expected achievement.

In addition to technical and intelligent mastery in managing emotions, it must of course be supported by good physical condition. Without good physical condition or physical ability is one of the basic components to achieve achievements in sports, especially martial arts combat. Some physical conditions that need to be considered and developed are cardiovascular endurance, endurance strength, muscle strength (strength), flexibility (flexibility), and power. To improve the components of good physical condition, training is needed, because the better the physical condition or physical ability of a person, the opportunity for achievement is also greater. The opposite is true, the lower the level of physical condition the more difficult it is to achieve.

In achieving achievement, a degree fighter must master all the elements that exist in the fight fighter itself such as punches, kicks, fights, and various other basic techniques. Kick is an attack whose value is higher than the blow attack. In addition, kick is one of the attacks that can bring down opponents quickly. The kick technique consists of the inner ring, side kick, back ring, back kick, front kick, and back hook kick.

One of the kicks that is often done in matches is a side kick. The side kick is one of the most dominant techniques in producing points in a match. Side kicks are kicks taken with the body position sideways while the kicking leg is in the form of a foot with the target body or head, the position of the hand still protects the jaw and face. The side kicks must have speed so that they fit right into the target and produce a number for the athlete itself. The accurate side kick is balanced by coaching several components of the athlete's physical condition.

Side kick capabilities include: strength, endurance, speed, flexibility, leg muscle explosive power, and endurance, each of which must be built through the stages of training in each of which must be built through the stages of training of each periododisator (Johansyah, 2013: 61) [3]. Of the components that affect the ability of the side kick, it is necessary to get training in accordance with the portion, because the components have differences in the form of movement, training methods, training load, and so forth.

Based on the monitoring of researchers that occurred in the field, the achievements of combat athletes in the city of Padang have decreased and increased performance. This is evidenced by the various achievements achieved from 2014 to 2018 which have decreased. In 2014, the fighters in Padang City 
experienced a decrease, namely only getting 2 bronze medals in the West Sumatra PORPROV XIII 2014 in Kab. Dharmasraya. In 2016, the Padang combatant degree in Kota Padang has increased which won 5 silver and 2 per week at the 2016 West Sumatra PORPROV XIV in Padang City. Then in 2018 Padang City combat athletes have experienced a significant increase and won 3 overall championship which won 3 gold, 1 silver and 1 bronze in West Sumatra PORPROV XIV in 2018 in the district. Padang Pariaman.

Based on the observation of researchers that PORPROV athletes fight in Padang City degree, the side kick ability possessed by athletes is still not maximal in the match so that when competing they often lose speed and power with athletes from other regions. It can be seen, that the kicks kicked by athletes often deviated or not on target. That is, the ability of an athlete's kick is easily anticipated by the opponent so as to produce points or numbers for the opponent.

The Tarung Derajat Athletes of the City of Padang currently carry out training and development of degree fighting, especially in the fields of engineering, physical abilities, strategies, and mental abilities in competition. This program certainly aims to improve the ability of Padang City degree combatants, because a fighter is in need of maximum physical condition and achievement of Padang City level fighter athletes.

Physical conditions in sports are all physical abilities that are accumulated to determine achievement. This depends on the realization of the athlete's personal ability (ability and motivation). The realization of all physical abilities is of course a function of physical elements whose roles vary from one physical condition to another, if athletes have excellent physical conditions, in addition to good technical, tactic, and mental elements, then to excel will be better (Alnedral in Achmad Drajat, 2007: 5) [4]. Based on the description above, it can be concluded that the achievement of fighting degrees is influenced by various aspects and factors in training. Departing from the problems that have been explained, the researchers were encouraged to examine the "Effect of Leg Muscle Strength, Leg Muscle Explosion Power and Reactivity Speed on the Ability of the Side Kicking in the Padang Tarung Derajat Sports Branch".

\section{METHODS}

The method used in this research is quantitative with the Path Analysis approach. According to Streiner (2005) in Sarwono and Budiono (2012: 207), "path analysis is an extension of multiple linear regression, and that allows the analysis of more complex models"[5].
This research was carried out in the Degrees Crater of the West Sumatra Provincial Government in Padang City athletes. The time of the study was from July to August 2019.

The population in this study were all combat athletes in the city of Padang who were still active as many as 110 people, consisting of 60 men and 50 women. Sampling in this study using purposive sampling technique, which is based on consideration of the goals set by researchers, so that the sample in this study were 60 male athletes.

The instruments in this study, namely leg muscle strength with a Legynometer, explosive power of the leg muscles with Standing Broad Jump, reaction speed using leg reaction speed and side kick capability by doing side kicks for 1 minute.

The analysis technique used in submitting hypotheses is Path Analysis. Data analysis includes: 1) data description, 2) test requirements analysis consisting of: normality test, Linearity test and Multicollinearity test, 3) path analysis covering, model testing and hypothesis testing.

\section{RESULT AND DISCUSSION}

Based on testing the first hypothesis, that there is a direct effect on the strength of leg muscles (X1) on the ability of side kicks (Y) athletes in Padang degree combat sports. The magnitude of this effect can be seen in the coefficient table, namely py $1=0.289$ and Sig. $=$ $0.007<\alpha=0.05$. The results of this study indicate that the magnitude of the direct influence of leg muscle strength on the side kick ability of the fighting athletes in Padang City degree is $8.35 \%$, while the rest are other factors not explained in this study.

The second hypothesis testing, that there is a direct influence of leg muscle explosive power (X2) on the ability of side kick $(\mathrm{Y})$ athletes in Padang fighting degree. The magnitude of this effect can be seen in the coefficient table, namely py $2=0.345$ and Sig. $=0.003$ $<\alpha=0.05$. The results of this study indicate that the magnitude of the direct influence of leg muscle explosive power (X2) on the side kick capability (Y) of athletes in Padang City fighting degree is $11.90 \%$, while the rest are other factors not explained in this study.

The third hypothesis testing, that there is a direct influence on the speed of reaction (X3) on the ability of side kick (Y) athletes in Padang fighting degree. The magnitude of this effect can be seen in the coefficient table, namely py $3=0.293$ and Sig. $=0.022$ $<\alpha=0.05$. The results of this study indicate that the magnitude of the direct effect of reaction speed on the ability of side kicks in Padang City fighting athletes is $8.58 \%$, while the rest are other factors not explained in this study. 
The fourth hypothesis testing, the test results of the analysis of the variable leg muscle strength (X1) to the ability of the side kick (Y) through the reaction speed (X3) athletes degree fighting sports Padang City, obtained py $31=0.1058$. It can be said, that the magnitude of the indirect effect of leg muscle strength on the ability of the side kick through the reaction speed of the degree fighting athletes in Padang City is $10.58 \%$, while the rest are other factors not explained in this study.

The fifth hypothesis testing, the test results of the analysis of the leg muscle explosive power variable (X2) to the ability of the side kick (Y) through the reaction speed (X3) athletes degree fighting sports Padang City, obtained py32 $=0.1468$. It can be said, that the magnitude of the indirect effect of leg muscle explosive power on the ability of the side kick through the reaction speed of the degree fighting athletes in Padang City is $14.68 \%$, while the rest are other factors not explained in this study.

The sixth hypothesis testing, the results of the analysis of the variables of leg muscle strength (X1), leg muscle explosive power (X2) and reaction speed (X3) simultaneously on the side kick capability (Y) athletes fighting sports degree in Padang, obtained py321 = 0.562 . It can be said, that the magnitude of the influence of leg muscle strength, leg muscle explosive power and the speed of simultaneous reaction to the side kick ability of athletes in Padang degree combat sports is $56.20 \%$, while the rest are other factors not explained in this study.

Strength is the ability of a muscle to generate tension against a prisoner or a component of a physical condition which involves the ability of an athlete when using his muscles to receive a burden in a certain work time. Strength is a very important basic component of physical condition. According to Bompa in Syafruddin (2011: 70) said, "strength can be defined as the ability of nerve muscles to cope with internal and external loads"[6]. while according to Widiastuti (2011: 76) said, "physiologically muscle strength is the ability of a muscle or group of muscles to perform a maximum contraction against resistance or load, whereas mechanically muscle strength is defined as the force that can be generated by muscles or a group of muscles in a maximum contraction ".

Strength has become the most dominant element among the elements of other physical conditions in the ability to do side kicks. Strength in doing side kicks has the role of producing hard kicks so that kicks are difficult to anticipate by opponents who ultimately produce points or points. Leg muscle strength possessed by combat athletes degree, divided into three namely: maximum strength, speed strength and endurance strength.

Explosive power is a combination of the physical elements of strength and speed. That is, the ability of explosive power can be seen from the results of a performance that uses strength and speed. According to Bafirman, (1999: 71) "Explosive power is one of the important biomotor components in sports activities". because explosive power will determine how hard people can hit, how far to throw, how high they jump, how fast they run and so on. In other words, explosive power can be interpreted as the ability to display or release force explosively or quickly[7]. In addition to leg muscle strength, the physical component needed by athletes fighting in the degree of Padang City doing side kicks is leg muscle explosive power, because leg muscle strength alone will not be enough without having leg muscle explosive power so that the ability of side kicks can be maximized. Athletes degree fighting Padang City which has good leg muscle strength without being equipped with leg muscle explosive power, then the ability to do side kicks will not be maximized. The explosive power of leg muscles in side kicks plays a role in producing kicks that are not only hard but also maximally fast so that kicks that are made are difficult to anticipate by opponents who ultimately produce points or points.

In addition, leg muscle strength and leg muscle explosive power, the physical component that must be possessed by athletes is the speed of reaction in doing side kicks. Speed is one of the biomotor components needed in the Tarung Derajat sport. Speed is an essential physical component. In the sports branch of Tarung Derajat specifically kick, speed is a determining factor and is very necessary, both to carry out attacks and for defense. According to Syafruddin (2012: 87), speed is very dependent on strength (direct) because without strength, speed cannot be developed[6]. If an athlete wants to develop his maximum speed then he must also develop his strength. This is due to the ability of speed obtained depends on the impulses (impulses) of strength and is a product of the body's mass and speed of the body itself, so there is a negative correlation between strength and speed in overcoming external loads. Whereas what is meant by reaction speed is the ability to respond to stimuli quickly. The reaction speed in the side kick has a role to produce a kick so that it is faster, more agile, and on target in the face of an opponent so that the kick taken is difficult to anticipate by the opponent who ultimately produces a point or point.

The results of this study explain, that the ability of the side kick is influenced by these three factors or it can be interpreted, that the side kick capability of the fighting athletes in Padang City can be maximized if it 
has variable leg muscle strength, leg muscle strength and speed of reaction.

\section{CONCLUSION}

Based on data analysis and discussion, it can be concluded that:

1. There is a direct influence on leg muscle strength on the side kick ability of athletes in the Tarung Derajat Padang Padang.

2. There is a direct influence of leg muscle explosive power on the ability to kick side athletes in the sports branch of Tarung Derajat, Padang City.

3. There is a direct influence on the speed of reaction to the side kick ability of athletes in the Tarung Derajat Padang city.

4. There is an indirect effect of leg muscle strength on the ability of side kicks through the reaction speed of athletes in the Tarung Derajat Padang City.

5. There is an indirect effect of leg muscle explosive power on the ability of side kicks through the reaction speed of athletes in the Tarung Derajat Padang City.

6. There is an influence of leg muscle strength, leg muscle explosive power and the speed of simultaneous reaction to the side kick ability of athletes in the sports field of Tarung Derajat Padang City.

\section{REFERENCES}

[1] PB KODRAT. 2013: Auran Pokok Perguruan Pusat Tarung Derajat \&Anggaran Dasar dan Anggaran Rumah Tangga PB KODRAT. Bandung: Perguruan Pusat Beladiri Tarung Derajat Bandung.

[2] Dradjat, Achmad Guru Haji. 2007. Kawah Dradjat Bandung: Pusat Pembinaan Moral dan Mental (MORTAL-GHADA) Bahan dan Pelatihan Tarung Derajat Tingkat Pelatihan Pengda KODRAT se Sumatera dilaksanakan di Padang.

[3] Lubis, Johansyah. 2004. Pencak Silat: Panduan Praktis, Jakarta: Rajawali Sport.

[4] Alnedral, 2009. Beladiri Tarung Derajat MorthalGhada: Sejarah, Pengembangan, dan Praktik, (online),www. Kawahderajatsumbar.com, diakses 23 Juni 2015.

[5] Sarwono, J dan Budiono, H. 2012. Statistik Terapan Aplikasi untuk Riset Skripsi, Tesis dan Disertasi. Jakarta : PT Elex Media Komputindo.

[6] Syafruddin, 2012. Ilmu Kepelatihan Olahraga: Teori dan Aplikasi dalam Pemnbinaan Olahraga. Padang: FIK-UNP.
[7] Bafirman. (Ed). 2000. Pembinaan Kondisi Fisik. Padang FIK-UNP.

[8] Undang-Undang Republik Indonesia Nomor 3 Tahun 2005 Tentang Sistem Keolahragaan Nasional. Jakarta: Biro Humas, Kementrian Pemuda Olahraga Republik Indonesia. 